\title{
When the user is not the chooser: stakeholder involvement in innovation adoption and implementation for addressing HCAIS
}

\author{
R Ahmad*, Y Kyratsis, A Holmes \\ From International Conference on Prevention \& Infection Control (ICPIC 2011) \\ Geneva, Switzerland. 29 June - 2 July 2011
}

\section{Introduction / objectives}

Whilst evidence based innovations exist for helping to address Health Care Associated Infections (HCAIs), the uptake and implementation of these is highly variable and in some cases very slow. We aimed to investigate organisational innovation adoption decisions and implementation processes in the context of Infection Prevention and Control (IPC). Here we focus on the implications of stakeholder involvement during these processes.

\section{Methods}

We sampled NHS trusts in England, which were winners of the Department of Health 'HCAI Technology Innovation Award 2009'. By analysing data from over $100 \mathrm{semi}$-structured qualitative interviews with clinical and non-clinical staff at all levels, we looked at technology selection decisions and implementation processes.

\section{Results}

Stakeholder involvement varied across the trusts with decisions highly exclusive to the IPC team, to highly inclusive of wider trust members. The context, including previous experience, and logistical factors influenced the level of stakeholder engagement. The method and timing of stakeholder involvement impacted on: the nature of innovations considered, innovations selected, success of the implementation of innovations. Cases of nonadoption and discontinued technologies are presented for important learning. Cases of successful implementation are presented in context of the adopting hospital. A model of potential benefits to 'successful' innovation adoption and implementation is presented.

Infectious diseases and Immunity, Imperial College London, London, UK

\section{Conclusion}

Key stakeholder involvement can lead to innovation adoption decisions compatible with structural and cultural contexts. There are potential synergies through stakeholder engagement across the two phases of decision making and implementation. Our model has useful application as a strategic and operational toolkit for IPC.

\section{Disclosure of interest}

None declared.

Published: 29 June 2011

doi:10.1186/1753-6561-5-S6-O36

Cite this article as: Ahmad et al:: When the user is not the chooser:

stakeholder involvement in innovation adoption and implementation

for addressing HCAIS. BMC Proceedings 2011 5(Suppl 6):O36.
Submit your next manuscript to BioMed Central and take full advantage of:

- Convenient online submission

- Thorough peer review

- No space constraints or color figure charges

- Immediate publication on acceptance

- Inclusion in PubMed, CAS, Scopus and Google Scholar

- Research which is freely available for redistribution 